\title{
Bolu İli Doğancı Köyü Erişsin Nüfusta Kalp ve Damar Hastalıkları için Risk Faktörleri Sıklı̆̆ı
}

\section{Frequency of Risk Factors for Cardiovascular Diseases in Adult Population of Doğanc1 Village, in Bolu}

\author{
İsmail Onur ${ }^{1}$, Aysu Kıyan², Seval Alkoy² \\ ${ }^{1}$ Sakarya İl Sağlık Müdürlü̆̆̈̈ \\ ${ }^{2}$ Abant İzzet Baysal Üniversitesi Tip Fakültesi, Halk Sağlı̆̆ı Anabilim Dalı, Bolu
}

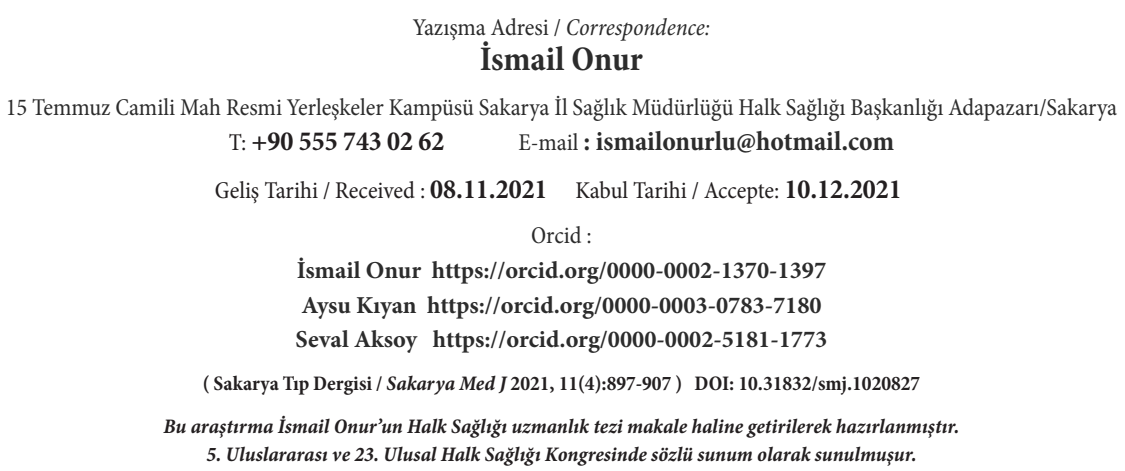

\footnotetext{
$\ddot{O} z$

Amaç Bu çalıșmada Bolu İli Doğancı Köyü’nde, erișkin nüfusta kalp ve damar hastalıkları için risk faktörü olduğu bilinen tütün ve alkol kullanımı, fiziksel aktivite, obezite ve hipertansiyon sıklı̆̆ı ve bunlarla ilişkili durumların ortaya konması amaçlanmıştır.

Yöntem ve Araștırma 957 erișkin nüfusu olan Doğancı Köyü’nde yürütülmüș; 796 (\%83,1) kișiye ulașıllmıș ve 749 (\%78,2) kiși ile tamamlanmıștır. Katılımcıların boy uzunluğu, vücut Gereçler ağırlığı, bel çevresi, kalça çevresi ve kan basıncı ölçümleri yapılmıştır.

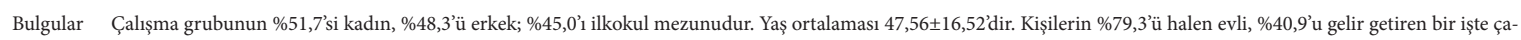
lışmaktadır. Çalışma grubunun \%26,7’si tütün ürünü, \%4,9’u alkol kullanmaktadır. Çalışma grubunun \%28,7’si orta düzey, \%32,6’sı ağır düzey fiziksel aktivite yapmaktadır. Kişilerin \%31,4'ü obez, \%56,7'sinin bel çevresi geniş, \%55,7'sinin bel kalça oranı fazladır. Çalışma grubunun \%37,7’sinde hipertansiyon tespit edilmiştir.

Sonuç Kalp ve damar hastalıkları risk faktörlerinden tütün ve alkol kullanımı erkeklerde, obezite ve hipertansiyon kadınlarda daha fazla görülmektedir.

Anahtar $\quad$ Kalp ve damar hastalıkları; tütün kullanımı; alkol içme; obezite; hipertansiyon
Kelimeler
}

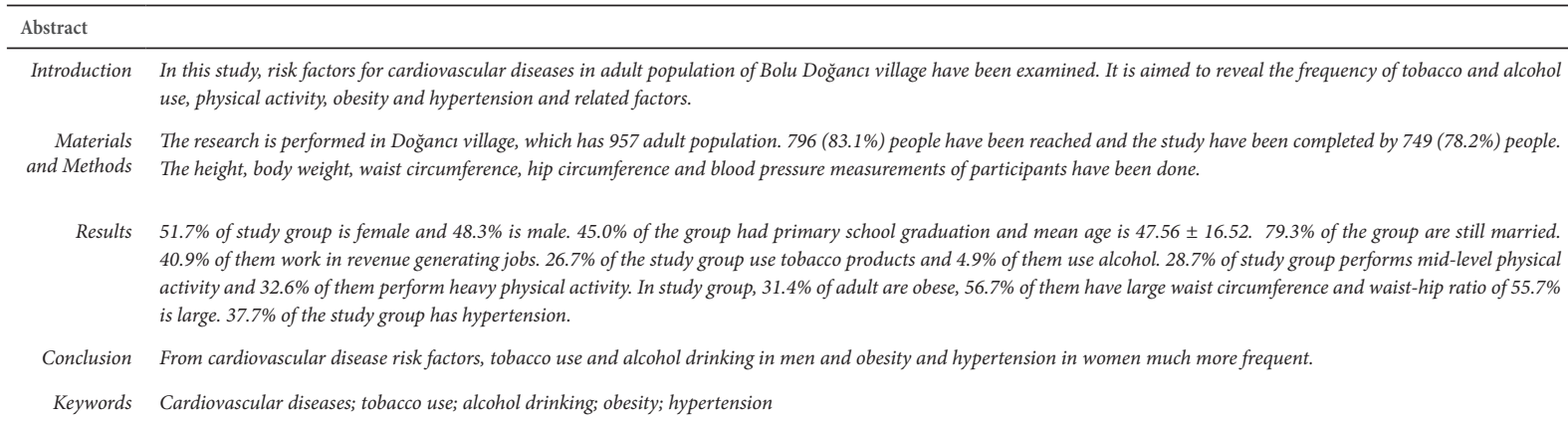




\section{GİRIŞ}

Kronik hastalıklar "tam olarak tedavi edilemeyen ve iyileşme göstermeyen uzamış durumlar” olarak tanımlanmaktadır. Bütün dünyada olduğu gibi ülkemizde de bulaşıcı olmayan hastalıkların görülme sıklığı ve ölüm nedenleri içindeki payı giderek artmaktadır. Kronik hastalıklar çerçevesinde en büyük payı kalp ve damar hastalıkları almaktadir. $^{1}$

Türkiye İstatistik Kurumu (TUİK) 2019 verilerine göre ülkemizde ölümlerin \%36,8'i dolaşım sistemi hastalıklarına bağlıdır. Dolaşım sistemi hastalıkları ölümleri incelendiğinde, ölenlerin \%39,1'inin iskemik kalp hastalığından, \%22,2'sinin kalp ve damar hastalıklardan, \%25,7'sinin diğer kalp hastalıklarından öldüğü görülmüştür. ${ }^{2}$

Kalp ve damar hastalıkları için başlıca risk faktörleri tütün ve alkol kullanımı, sağlıksız beslenme ve yetersiz fiziksel aktivitedir. Bu risk faktörlerine bağlı yüksek kan basıncı, yüksek kan şekeri, bozuk kan lipit düzeyleri ve obezite ortaya çıkmaktadır. DSÖ birinci basamakta kalp ve damar hastalıkları risk faktörlerine yönelik kronik hastalık risk faktörleri sürveyansında basamaklı yaklaşımı geliştirmiştir. Bu yaklaşım sosyodemografik özellikleri, tütün ve alkol kullanımı, beslenme davranışları ve fiziksel aktiviteyi sorgulayan birinci adım; tansiyon, boy, vücut ağırlığı, bel ve kalça çevresi ölçümlerini içeren ikinci adım ve kan şekeri, kan yağlarını içeren üçüncü adımdan oluşmaktadır. ${ }^{3}$

Bu çalışmada Bolu İli Doğancı Köyü’nde kalp ve damar hastalıkları için risk faktörlerine yönelik tütün, alkol kullanımı, fiziksel aktivite, obezite ve hipertansiyon sıklığının yaş, cinsiyet, eğitim gibi sosyodemografik değişkenlere göre dağılımlarının gösterilmesi amaçlanmıştır.

\section{GEREÇ ve YÖNTEM}

$\mathrm{Bu}$ çalışma kesitsel tipte tanımlayıcı bir araştırmadır. Doğancı Köyü’nde ikamet eden 957 erişkin araştırmanın evrenini oluşturmaktadır. Araştırmada 796 (\%83,1) kişiye ulaşılmış ve $749(\% 78,2)$ kişi ile araştırma tamamlanmıştır.
18 yaş altı bireyler, gebeler, araştırmaya katılımı kabul etmeyenler ve sağlıklı iletişim kurulamayanlar (demans, ağır mental retarde, vb.) çalışma dışı bırakılmıștır. Araştırmanın bağımsız değişkenleri yaş, cinsiyet, eğitim durumu, gelir getiren bir işte çalışma durumu, medeni durum, sağllk güvencesi varlığı, gelir durumu ve aile tipidir. Bağımlı değişkenleri ise risk faktörleri olan tütün ve alkol kullanımı, fiziksel aktivite, obezite ve kan basıncı yüksekliğidir.

\section{Ölçümler}

Tansiyon ölçümü Halk Sağlığı Araştırma Görevlisi Doktor koordinasyonunda son sinıf tıp fakültesi öğrencileri tarafından, klasik oskültatuvar yöntemli tansiyon aleti ile yapılmıştır. Tansiyon ölçümünde kalibrasyonu yapıldığ 1 bilinen Erka Perfect Aneroid 13*47 cm erişkin tipi 4 adet manometreli tansiyon ölçüm aleti ve 4 adet $3 \mathrm{M}^{\mathrm{m} N}$ Littmann $^{\star}$ Classic II S.E. marka steteskop kullanılmıştır. Ölçüm öncesi kişinin oturur durumda en az 5 dakika dinlenmesi sağlanıp, avuç açık, sağ kolun kalp seviyesinde olması sağlanmıştır. Araştırmacılar tarafından 4 adet Sinbo SBS-414 Dijital Cam Baskül (100 gr hassasiyet) ile vücut ağırlığı, 4 adet $150 \mathrm{~cm}$ ve $300 \mathrm{~cm}$ 'lik standart mezura kullanılarak bel, kalça çevresi ve kişinin boyu ölçülmüştür. Vücut ağırlığı, sert zemin üzerinde, üzerlerindeki fazla (ayakkabı, kazak, hırka, ceket vs.) giysiler çıkarılarak ölçülmüştür. Boy, düz bir duvara ayakları sert zeminde, ayak topukları duvara değecek biçimde yaslanarak, ayakkabısız olarak ölçülmüştür. Bel çevresi, kişi ayakta üzerindeki giysi sıyr1larak mezura ile subcostal bölge ile krista iliaka arasındaki en dar bölgeden yapılan ölçümle kaydedilmiştir. Kalça çevresi, arkada gluteus maksimuslar önde pubis üzerinden geçen en geniş vücut çapı esas alınarak ölçülmüştür. Kan basıncı milimetre/cıva (mmHg), vücut ağırlığı kilogram $(\mathrm{kg})$, boy, bel ve kalça çevresi santimetre $(\mathrm{cm})$ biriminden hesaplanmıştır.

Tütün ürünü kullanımı sigara, nargile ve diğer tütün ürününden herhangi birini kullanmak olarak tanımlanmıştır. Alkol kullanımı standart içki ile belirlenmiş; 1 küçük bira (330 cc), 1 kadeh şarap (125 cc), 1 tek rakı (85 ml), 1 tek 
votka $(100 \mathrm{ml}) 1$ standart içki olarak kabul edilmiştir. ${ }^{4}$

En az 10 dakika süren kalp atışını ya da solunumu ağır düzeyde artıran koşma, hızlı tempo yürüme, yüzme, atlama, ağır kaldırma, odun kesme, bahçede çukur kazma gibi eylemler ağır düzey fiziksel aktivite olarak kabul edilmiştir. En az 10 dakika süren kalp atışı ya da solunumu orta düzeyde artıran yürüyüş, bisiklete binme hafif bahçe işleri orta düzey fiziksel aktivite olarak kabul edilmiştir. Orta ve ağır düzey fiziksel aktivite yapanlar fizikselsel aktivite yapıyor olarak değerlendirilmiştir. ${ }^{4}$

Beden kitle indeksi (BKİ) bireyin kilogram cinsinden vücut ağırlığının, metre cinsinden boy uzunluğunun karesine bölünmesiyle elde edilen bir değerdir $\left(B K I ̇=\mathrm{kg} / \mathrm{m}^{2}\right)$. BKI $30 \mathrm{~kg} / \mathrm{m}^{2}$ ve üzeri olması obezite olarak kabul edilmiştir. Bel çevresinin erkekte $102 \mathrm{~cm}$, kadında ise $88 \mathrm{~cm}$ ve üzerinde olması "geniş bel çevresi” olarak tanımlanmıştır. Bel kalça oranı (BKO) bel çevresinin kalça çevresine bölümü ile elde edilmiş; BKO erkeklerde 0,95, kadınlarda 0,88'in üzerinde olanlar "riskli/fazla" olarak kabul edilmiştir. ${ }^{4}$

Ofis ya da klinikte ölçülen Sistolik kan basıncı $\geq 140$ $\mathrm{mmHg}$ ve/veya diyastolik kan basınc $\geq 90 \mathrm{mmHg}$ olması hipertansiyon olarak tanımlanmıştır. ${ }^{4}$ Daha önce bir hekim tarafından hipertansiyon tanısı konulan ve ölçümler sonucu sistolik kan basinc1 $\geq 140 \mathrm{mmHg}$ ve/veya diyastolik kan basıncı $\geq 90 \mathrm{mmHg}$ üzerinde saptananlar hipertansiyon sıklığına dahil edilmiştir.

Araştırma için Abant İzzet Baysal Üniversitesi Sosyal Bilimlerde İnsan Araştırmaları Etik Kurulundan 09.12.2015 tarihli toplantısında 2015/163 protokol numarası ile etik izin alınmıştır. Araştırmanın yapılabilmesi için Bolu Valiliği İl Halk Sağlığı Müdürlüğünden 11.12.2015 tarihli 78102020/779 sayılı yazısı ile gerekli onay alınmış, Refika Baysal Toplum Sağlığı Merkezi ve Doğancı Aile Sağlığı Merkezine bilgi verilmiştir. Çalışmaya başlamadan önce kişilere çalışma hakkında bilgi verilmiş, bilgilendirme ve onam formları okutulmuş, onamları alınmıştır.
Araştırma sonucunda elde edilen veriler bilgisayara aktarılmış ve analizleri bilgisayar ortamında SPSS 15.0 sürümü kullanılarak yapılmıştır. Sayımla belirtilen verilerin tanımlayıcı bulguları frekans dağılımı ve yüzde olarak, ölçümle belirtilen verilerin tanımlayıcı bulguları ise ortalama, standart sapma, ortanca, en küçük ve en büyük değerlerle gösterilmiştir. Bağımsız iki grupta nitel verilerin karşılaştırılmasında ki-kare testi kullanılmıştır. $\mathrm{p}<0,05$ düzeyi istatistiksel açıdan anlamlı olarak kabul edilmiştir.

\section{BULGULAR}

Çalışma grubunun \%48,3'ü erkek, \%51,7'si kadındır. Katılımcıların \%19,8'i 30-39 yaş, \%19,0'1 40-49 yaş, \%19,5'i 50-59 yaş aralığında, \%45,0’ı ilkokul mezunu, \%79,3’ü evli, \%40,9’u gelir getiren bir işte çalışmakta, \%97,3’ü Sosyal Güvenlik Kurumu üzerinden sağlık sigortasına sahip, $\% 65,1$ 'i çekirdek ailede yaşamakta, \%65,6'sı kendisini orta gelir düzeyinde tanımlamaktadır. Katılımcıların sosyodemografik özellikleri Tablo 1'de gösterilmiştir. 
Tablo 1: Katılımcıların Sosyodemografik Özellikleri, Bolu

Doğanc1, 2015.

\begin{tabular}{|c|c|c|c|}
\hline \multicolumn{2}{|c|}{ Sosyodemografik Özellik (n=749) } & Say1 & $\%$ \\
\hline \multirow{2}{*}{ Cinsiyet } & Erkek & 362 & 48,3 \\
\hline & Kadın & 387 & 51,7 \\
\hline \multirow{6}{*}{ Yaş } & $18-29$ & 114 & 15,2 \\
\hline & $30-39$ & 149 & 19,8 \\
\hline & $40-49$ & 142 & 19,0 \\
\hline & $50-59$ & 146 & 19,5 \\
\hline & $60-69$ & 121 & 16,2 \\
\hline & 70 yaş ve üzeri & 77 & 10,3 \\
\hline \multirow{6}{*}{ Öğrenim durumu } & Okuryazar Değil & 59 & 7,9 \\
\hline & Okuryazar & 52 & 6,9 \\
\hline & İlkokul & 337 & 45,0 \\
\hline & Ortaokul & 77 & 10,3 \\
\hline & Lise & 162 & 21,6 \\
\hline & Üniversite & 62 & 8,3 \\
\hline \multirow{5}{*}{ Medeni durum } & Evli & 594 & 79,3 \\
\hline & Hiç Evlenmemiş & 86 & 11,5 \\
\hline & Eşi Ölmüş & 56 & 7,5 \\
\hline & Boşanmış & 10 & 1,3 \\
\hline & $\begin{array}{l}\text { Halen Evli Olup } \\
\text { Ayrı Yaşayan }\end{array}$ & 3 & 0,4 \\
\hline \multirow[t]{2}{*}{ Çalışma Durumu } & $\begin{array}{l}\text { Gelir Getiren Bir } \\
\text { İște Çalışan }\end{array}$ & 306 & 40,9 \\
\hline & Çalışmayan & 443 & 59,1 \\
\hline \multirow{6}{*}{ Sağlık Güvencesi } & SSK & 533 & 71,1 \\
\hline & Emekli Sandığı & 102 & 13,6 \\
\hline & Bağkur & 83 & 11,1 \\
\hline & $\begin{array}{l}\text { Genel Sağllk } \\
\text { Sigortası }\end{array}$ & 11 & 1,5 \\
\hline & $\begin{array}{l}\text { Özel Sağlık } \\
\text { Sigortası }\end{array}$ & 2 & 0,3 \\
\hline & $\begin{array}{l}\text { Sağllk Güvencesi } \\
\text { Olmayan }\end{array}$ & 18 & 2,4 \\
\hline \multirow{3}{*}{ Aile Tipi } & Çekirdek Aile & 488 & 65,1 \\
\hline & Geniş Aile & 253 & 33,8 \\
\hline & $\begin{array}{c}\text { Tek Ebeveynli } \\
\text { Aile }\end{array}$ & 8 & 1,1 \\
\hline \multirow{3}{*}{ Gelir Düzeyi } & Düşük & 228 & 30,4 \\
\hline & Orta & 491 & 65,6 \\
\hline & Yüksek & 30 & 4,0 \\
\hline
\end{tabular}

Çalışmaya katılan erkeklerin \%43,9'u kadınların \%10,6’sı tütün ürünü kullanmaktadır. Tütün ürünü kullanımı 50 yaş altında $\% 36,8$, lise ve üzeri öğrenim görenlerde $\% 41,6$, evli olanlarda $\% 26,3$, bekarlarda ise $\% 40,7^{\prime}$ dir. Gelir getiren bir işte çalışanların \%46,1'i, tek ebeveyn-çekirdek ailede yaşayanların \%31,0’1 tütün ürünü kullanmaktadır. Erkekler kadınlara göre, 50 yaş altındakiler 50 yaş ve üzerindekilere göre, lise ve üzeri mezuniyeti olanlar lise altı öğrenim görenlere göre, bekar olanlar evli-evli olup ayrı yaşayan ve boşanmış-eşi ölmüşlere göre, gelir getiren bir işte çalışanlar çalışmayanlara göre, çekirdek-tek ebeveynli ailede yaşayanlar geniş ailede yaşayanlara göre tütün ürünlerini istatistiksel olarak anlamlı düzeyde fazla tüketmektedir. Katılımcıların sosyodemografik özelliklerinin tütün ürünü kullanımına etkisi Tablo 2'de gösterilmiştir.

Araştırmaya katılan erkeklerin \%8,8'i, kadınların \%1,3’ü alkol kullanmaktadır. Alkol kullanımı 50 yaş altında \%6,9, bekarlarda \%14,0'dır. Gelir getiren bir iște çalışanların $\% 8,8$ 'i, algılanan gelir düzeyine göre düşük geliri olanların \%7,9'u alkol kullanmaktadır. Erkekler kadınlara göre, 50 yaş altındakiler 50 yaş ve üzerindekilere göre, bekar olanlar evli-evli olup ayrı yaşayan ve boşanmış-eşi ölmüşlere göre, gelir getiren bir işte çalışanlar çalışmayanlara göre, gelir düzeyini düşük olarak tanımlayanlar orta ve yüksek olarak tanımlayanlara göre alkolü istatistiksel olarak anlamlı düzeyde fazla tüketmektedir. Katılımcıların sosyodemografik özelliklerinin alkol kullanımına etkisi Tablo 3’te gösterilmiştir.

Çalıșmaya katılan erkeklerin \%65,7'si kadınların \%57,1'i, boşanmış-eşi ölmüş olanların \%47,0'1, algılanan gelir düzeyine göre yüksek geliri olanların ise $\% 80,0$ '1 fiziksel aktivite yapmaktadır. Erkekler kadınlara göre, gelir düzeyini yüksek olarak tanımlayanlar orta ve düşük olarak tanımlayanlara göre anlamlı düzeyde daha fazla fiziksel aktivite yaparken; boşanmış-eşi ölmüşler, evli-evli olup ayrı yaşayan ve bekarlara göre anlamlı düzeyde daha az fiziksel aktivitede bulunmaktadır. Sosyodemografik özelliklerin fiziksel aktivite üzerine etkisi Tablo 4’te gösterilmiştir. 
Sakarya Tip Dergisi 2021;11(4):897-907

ONUR ve Ark., Kalp ve Damar Hastalıkları Risk Faktörleri

\begin{tabular}{|c|c|c|c|c|c|c|c|}
\hline \multirow{3}{*}{\multicolumn{2}{|c|}{ Sosyodemografik Özellikler }} & \multicolumn{4}{|c|}{$\begin{array}{l}\text { Tütün Ürünü Kullanma Durumu } \\
\qquad(\% 26,7)\end{array}$} & \multirow{3}{*}{$\chi^{2}$} & \multirow{3}{*}{$\mathbf{p}$} \\
\hline & & \multicolumn{2}{|c|}{$\begin{array}{c}\text { Kullanan } \\
(\mathbf{n}=\mathbf{2 0 0})\end{array}$} & \multicolumn{2}{|c|}{$\begin{array}{c}\text { Kullanmayan } \\
(\mathrm{n}=549)\end{array}$} & & \\
\hline & & Sayı & $\%$ & Sayı & $\%$ & & \\
\hline \multirow{2}{*}{ Cinsiyet } & Erkek & 159 & 43,9 & 203 & 56,1 & \multirow{2}{*}{106,12} & \multirow{2}{*}{0,0006} \\
\hline & Kadın & 41 & 10,6 & 346 & 89,4 & & \\
\hline \multirow{2}{*}{ Yaş } & 50 Yaş Altı & 149 & 36,8 & 256 & 63,2 & \multirow{2}{*}{45,850} & \multirow{2}{*}{0,001} \\
\hline & 50 Yaş ve Üzeri & 51 & 14,8 & 293 & 85,2 & & \\
\hline \multirow{2}{*}{ Öğrenim Düzeyi } & Lise Altı & 108 & 20,6 & 417 & 79,4 & \multirow{2}{*}{33,713} & \multirow{2}{*}{0,0006} \\
\hline & Lise ve Üzeri & 92 & 41,1 & 132 & 58,9 & & \\
\hline \multirow{3}{*}{ Medeni Durum } & Evli-Evli Olup Ayrı Yaşayan & 157 & 26,3 & 440 & 73,7 & \multirow{3}{*}{15,826} & \multirow{3}{*}{0,0003} \\
\hline & Boşanmış-Eşi Ölmüş & 8 & 12,1 & 58 & 87,9 & & \\
\hline & Bekar & 35 & 40,7 & 51 & 59,3 & & \\
\hline \multirow{2}{*}{ Çalışma Durumu } & Gelir Getiren Bir İşte Çalışıyor & 141 & 46,1 & 165 & 53,9 & \multirow{2}{*}{99,242} & \multirow{2}{*}{0,0002} \\
\hline & Çalışmıyor & 59 & 13,3 & 384 & 86,7 & & \\
\hline \multirow{2}{*}{ Aile Tipi } & Çekirdek-Tek Ebeveyn & 154 & 31,0 & 342 & 69,0 & \multirow{2}{*}{15,601} & \multirow{2}{*}{0,0004} \\
\hline & Geniş Aile & 46 & 23,0 & 207 & 81,8 & & \\
\hline
\end{tabular}

\begin{tabular}{|c|c|c|c|c|c|c|c|}
\hline \multirow{3}{*}{\multicolumn{2}{|c|}{ Sosyodemografik Özellikler }} & \multicolumn{4}{|c|}{ Alkol Kullanma Durumu $(\% 4,9)$} & \multirow{3}{*}{$\chi^{2}$} & \multirow{3}{*}{$\mathbf{p}$} \\
\hline & & \multicolumn{2}{|c|}{$\begin{array}{c}\text { Kullanan } \\
(\mathbf{n}=37)\end{array}$} & \multicolumn{2}{|c|}{$\begin{array}{l}\text { Kullanmayan } \\
\qquad(n=712)\end{array}$} & & \\
\hline & & Sayı & $\%$ & Sayı & $\%$ & & \\
\hline \multirow{2}{*}{ Cinsiyet } & Erkek & 32 & 8,8 & 330 & 91,2 & \multirow{2}{*}{22,691} & \multirow{2}{*}{0,0001} \\
\hline & Kadın & 5 & 1,3 & 382 & 98,7 & & \\
\hline \multirow{2}{*}{ Yaş } & 50 Yaş Altı & 28 & 6,9 & 377 & 93,1 & \multirow{2}{*}{7,315} & \multirow{2}{*}{0,007} \\
\hline & 50 Yaş ve Üzeri & 9 & 2,6 & 335 & 97,4 & & \\
\hline \multirow{3}{*}{ Medeni Durum } & Evli-Evli Olup Ayrı Yaşayan & 22 & 3,7 & 575 & 96,3 & \multirow{3}{*}{16,903} & \multirow{3}{*}{0,0002} \\
\hline & Boşanmış-Eşi Ölmüş & 3 & 4,5 & 63 & 95,5 & & \\
\hline & Bekar & 12 & 14,0 & 74 & 86,0 & & \\
\hline \multirow{2}{*}{ Çalışma Durumu } & Gelir Getiren Bir İşte Çalışıyor & 27 & 8,8 & 279 & 91,2 & \multirow{2}{*}{16,617} & \multirow{2}{*}{0,0004} \\
\hline & Çalışmıyor & 10 & 2,3 & 433 & 97,7 & & \\
\hline \multirow{3}{*}{ Gelir Düzeyi } & Düşük & 18 & 7,9 & 210 & 92,1 & \multirow{3}{*}{6,101} & \multirow{3}{*}{0,047} \\
\hline & Orta & 18 & 3,7 & 473 & 96,3 & & \\
\hline & Yüksek & 1 & 3,3 & 29 & 96,7 & & \\
\hline
\end{tabular}


Sakarya Tip Dergisi 2021;11(4):897-907

ONUR ve Ark., Kalp ve Damar Hastalıkları Risk Faktörleri

\begin{tabular}{|c|c|c|c|c|c|c|c|}
\hline \multirow{3}{*}{\multicolumn{2}{|c|}{ Sosyodemografik Özellikler }} & \multicolumn{4}{|c|}{ Fiziksel Aktivite Yapma Durumu $(\% 61,3)$} & \multirow{3}{*}{$\chi^{2}$} & \multirow{3}{*}{$\mathbf{p}$} \\
\hline & & \multicolumn{2}{|c|}{$\begin{array}{c}\text { Yapan } \\
(\mathrm{n}=459)\end{array}$} & \multicolumn{2}{|c|}{$\begin{array}{c}\text { Yapmayan } \\
(\mathrm{n}=290)\end{array}$} & & \\
\hline & & Sayı & $\%$ & Sayı & $\%$ & & \\
\hline \multirow{2}{*}{ Cinsiyet } & Erkek & 238 & 65,7 & 124 & 34,3 & \multirow{2}{*}{5,884} & \multirow{2}{*}{0,015} \\
\hline & Kadın & 221 & 57,1 & 166 & 42,9 & & \\
\hline \multirow{3}{*}{ Medeni Durum } & Evli-Evli Olup Ayrı Yaşayan & 373 & 62,5 & 224 & 37,5 & \multirow{3}{*}{6,317} & \multirow{3}{*}{0,042} \\
\hline & Boşanmış-Eşi Ölmüş & 31 & 47,0 & 35 & 53,0 & & \\
\hline & Bekar & 55 & 64,0 & 31 & 36,0 & & \\
\hline \multirow{3}{*}{ Gelir Düzeyi } & Düşük & 121 & 53,1 & 107 & 46,9 & \multirow{3}{*}{12,384} & \multirow{3}{*}{0,002} \\
\hline & Orta & 314 & 64,0 & 177 & 36,0 & & \\
\hline & Yüksek & 24 & 80,0 & 6 & 20,0 & & \\
\hline
\end{tabular}

Araştırmaya katılan erkeklerin \%22,9'u kadınların \%39,3'ü obezdir. Obezite sıklığı 50 yaş ve üzerinde $\% 43,3$, ortaokul ve altı öğrenim görenlerde ise \%36,8'dir. Çalışma grubunda evli olanların \%34,7'si, gelir getiren bir işte çalışmayanların \%37,0'ı obezdir. Kadınlarda erkeklere göre, 50 yaş ve üzerindekilerde 50 yaş altındakilere göre, lise altı öğrenimi olanlarda lise ve üzeri öğrenimi olanlara göre, gelir getiren bir işte çalışmayanlarda çalışanlara göre obezite istatistiksel anlamlı olarak daha fazladır. Bekarlar ise boşanmış-eşi ölmüşler ve evli-evli olup ayrı yaşayanlara göre anlamlı düzeyde daha az obezdir. Sosyodemografik özelliklerin obezite üzerine etkisi Tablo 5’te gösterilmiştir.

\begin{tabular}{|c|c|c|c|c|c|c|c|}
\hline \multirow{3}{*}{\multicolumn{2}{|c|}{ Sosyodemografik Özellikler }} & \multicolumn{4}{|c|}{ Obezite Durumu $(\% 31,4)$} & \multirow{3}{*}{$\chi^{2}$} & \multirow{3}{*}{$\mathbf{p}$} \\
\hline & & \multicolumn{2}{|c|}{$\begin{array}{c}\text { Obez Olan } \\
(n=235)\end{array}$} & \multicolumn{2}{|c|}{$\begin{array}{c}\text { Obez Olmayan } \\
(n=514)\end{array}$} & & \\
\hline & & Sayı & $\%$ & Sayı & $\%$ & & \\
\hline \multirow{2}{*}{ Cinsiyet } & Erkek & 83 & 22,9 & 279 & 77,1 & \multirow{2}{*}{23,128} & \multirow{2}{*}{0,0001} \\
\hline & Kadın & 152 & 39,3 & 235 & 60,7 & & \\
\hline \multirow{2}{*}{ Yaş } & 50 Yaş Altı & 86 & 21,2 & 319 & 78,8 & \multirow{2}{*}{42,115} & \multirow{2}{*}{0,0008} \\
\hline & 50 Yaş ve Üzeri & 149 & 43,3 & 195 & 56,7 & & \\
\hline \multirow{2}{*}{ Öğrenim Düzeyi } & Lise Altı & 193 & 36,8 & 332 & 63,2 & \multirow{2}{*}{23,658} & \multirow{2}{*}{0,0001} \\
\hline & Lise ve Üzeri & 42 & 18,8 & 182 & 81,2 & & \\
\hline \multirow{3}{*}{ Medeni Durum } & Evli-Evli Olup Ayrı Yaşayan & 207 & 34,7 & 390 & 65,3 & \multirow{3}{*}{24,587} & \multirow{3}{*}{0,0004} \\
\hline & Boşanmış-Eşi Ölmüş & 21 & 31,8 & 45 & 68,2 & & \\
\hline & Bekar & 7 & 8,1 & 79 & 91,9 & & \\
\hline \multirow{2}{*}{ Çalışma Durumu } & Gelir Getiren Bir İște Çalışıyor & 71 & 23,2 & 235 & 76,8 & \multirow{2}{*}{16,049} & \multirow{2}{*}{0,0006} \\
\hline & Çalışmıyor & 164 & 37,0 & 279 & 63,0 & & \\
\hline
\end{tabular}


Hipertansiyon sıklığı 50 yaş ve üzerinde $\% 58,7$, lise altı öğrenim görenlerde $\% 43,6$, boşanmış-eşi ölmüş olanlarda $\% 56,1$, gelir getiren bir işte çalışmayanlarda \%42,4’tür. 50 yaş ve üzerindekiler 50 yaş altındakilere göre, lise altı öğrenimi olanlar lise ve üzeri öğrenimi olanlara göre, boşanmış-eşi ölmüşler bekar ve evli-evli olup ayrı yaşayanlara göre, gelir getiren bir işte çalışmayanlar çalışanlara göre istatistiksel olarak anlamlı düzeyde daha fazla hipertansiyon hastasıdır. Sosyodemografik özelliklerin hipertansiyon sıklığı üzerine etkisi Tablo 6'da gösterilmiştir.
Obez olanların $\% 57,0$ ' 1 , bel çevresi geniş olanların $\% 43,5$ 'i, bel kalça oranı fazla olanların \%41,2'si hipertansiyon hastasıdır. Obezlerde, bel çevresi geniş olanlarda ve bel kalça oranı fazla olanlarda hipertansiyon istatistiksel anlamlı olarak daha fazladır. Obezitenin hipertansiyon sıklığı üzerine etkisi Tablo 7’de gösterilmiştir.

\begin{tabular}{|c|c|c|c|c|c|c|c|}
\hline \multirow{3}{*}{\multicolumn{2}{|c|}{ Sosyodemografik Özellikler }} & \multicolumn{4}{|c|}{ Hipertansiyon Durumu $(\% 37,6)$} & \multirow{3}{*}{$\chi^{2}$} & \multirow{3}{*}{$\mathbf{p}$} \\
\hline & & \multicolumn{2}{|c|}{$\begin{array}{c}\text { Hipertansiyon } \\
\text { Hastas1 } \\
(\mathbf{n}=\mathbf{2 8 2})\end{array}$} & \multicolumn{2}{|c|}{$\begin{array}{c}\text { Hipertansiyon } \\
\text { Hastasi Değil } \\
(n=467)\end{array}$} & & \\
\hline & & Sayı & $\%$ & Sayı & $\%$ & & \\
\hline \multirow{2}{*}{ Yaş } & 50 Yaş Altı & 80 & 19,8 & 325 & 80,2 & \multirow{2}{*}{120,321} & \multirow{2}{*}{0,0005} \\
\hline & 50 Yaş ve Üzeri & 202 & 58,7 & 142 & 41,3 & & \\
\hline \multirow{2}{*}{ Öğrenim Düzeyi } & Lise Alt1 & 229 & 43,6 & 296 & 56,4 & \multirow{2}{*}{26,642} & \multirow{2}{*}{0,0002} \\
\hline & Lise ve Üzeri & 53 & 23,7 & 171 & 76,3 & & \\
\hline \multirow{3}{*}{ Medeni Durum } & Evli-Evli Olup Ayrı Yaşayan & 226 & 37,9 & 371 & 62,1 & \multirow{3}{*}{18,407} & \multirow{3}{*}{0,0001} \\
\hline & Boşanmış-Eşi Ölmüş & 37 & 56,1 & 29 & 43,9 & & \\
\hline & Bekar & 19 & 22,1 & 67 & 77,9 & & \\
\hline \multirow{2}{*}{ Çalışma Durumu } & Gelir Getiren Bir İşte Çalışıyor & 94 & 30,7 & 212 & 69,3 & \multirow{2}{*}{10,588} & \multirow{2}{*}{0,001} \\
\hline & Çalışmıyor & 188 & 42,4 & 255 & 57,6 & & \\
\hline
\end{tabular}

\begin{tabular}{|c|c|c|c|c|c|c|c|}
\hline \multirow{3}{*}{ Obezite Belirteçleri } & & \multicolumn{4}{|c|}{ Hipertansiyon } & \multirow{3}{*}{$\chi^{2}$} & \multirow{3}{*}{ p } \\
\hline & & \multicolumn{2}{|c|}{$\begin{array}{c}\text { Hipertansiyon } \\
\text { Hastas1 } \\
(\mathbf{n}=\mathbf{2 8 2}) \\
\end{array}$} & \multicolumn{2}{|c|}{$\begin{array}{c}\text { Hipertansiyon } \\
\text { Hastası Değil } \\
(n=467)\end{array}$} & & \\
\hline & & Sayı & $\%$ & Sayı & $\%$ & & \\
\hline \multirow{2}{*}{ Obezite Durumu } & Obez Olan & 134 & 57,0 & 101 & 43,0 & \multirow{2}{*}{54,738} & \multirow{2}{*}{0,0001} \\
\hline & Obez Olmayan & 148 & 28,8 & 366 & 71,2 & & \\
\hline \multirow{2}{*}{ Bel Çevresi Genişliği } & Geniş Olan & 185 & 43,5 & 240 & 56,5 & \multirow{2}{*}{14,446} & \multirow{2}{*}{0,0001} \\
\hline & Geniș Olmayan & 97 & 29,9 & 227 & 70,1 & & \\
\hline \multirow{2}{*}{ Bel Kalça Oranı Fazlalığı } & Fazla Olan & 172 & 41,2 & 245 & 58,8 & \multirow{2}{*}{5,185} & \multirow{2}{*}{0,023} \\
\hline & Fazla Olmayan & 110 & 33,1 & 222 & 66,9 & & \\
\hline
\end{tabular}




\section{TARTIŞMA}

Tütün ürünü kullanımı kardiyovasküler hastalıklarda en önemli ve önlenebilir bir risk faktörü olarak kabul edilmektedir. Sigara 65 yaş öncesi görülen kalp ve damar hastalıklarından ölümlerin yaklaşık yarısından sorumlu tutulmaktadır. $^{5}$

Küresel Yetişkin Tütün Araştırması (KYTA) 2012 sonuçlarına göre erkeklerin 41,5'i, kadınların \%13,1'i sigara kullanmaktadır. ${ }^{6}$ KYTA 2016 sonuçlarına göre ise toplumda sigara içme sıklığı \%31,6 olup erkeklerin \%44,1'i kadınların \%19,2'si sigara kullanmaktadır.7 TUİK’in açıkladığı Türkiye Sağlık Araştırması 2019 verilerine göre 15 yaş ve üzeri nüfusta her gün tütün ürünü kullananların sıklığ1 2019 yılında \%28.0'dır. Bu sıklık erkeklerde \%41,3, kadınlarda ise \%14,9'dur. ${ }^{8}$

$\mathrm{Bu}$ çalışmada ise erkeklerin \%43,9’u, kadınların \%10,6’sı tütün ürünü kullanmaktadır (Tablo 2). Çalışmalar erkeklerin kadınlara oranla çok daha fazla tütün ürünü kullandığını göstermektedir. Geçen yıllar içerisinde erkeklerde benzer kullanım oranları olduğu, kadınların bir dönem kullanım sıklığının arttığı ancak son dönemde azalma eğiliminde olduğu görülmektedir. Çalışmanın kırsal alanda yürütülmesi kadınlarda tütün ürünü kullanımının aynı dönemde yapılan ulusal çalışmalardan az olmasını açıklayabilir.

Çalışma grubunda erkeklerin \%8,8'i, kadınların \%1,3’ü, toplamda \%4,9’u alkollü içecek kullanmaktadır (Tablo 3). Türkiye Beslenme Sağlık Araştırması (TBSA) 2010 sonuçlarına göre kırda alkol kullanımı \%13,8 oranında bulunmuştur.' Türkiye Hane Halkı Sağlık Araştırması 2017 yılında Türkiye genelinde seçilen örneklemde 6053 kişi üzerinde yürütülmüş olup, araştırmanın sonuçlarına göre alkol kullanımı erkeklerde \%13,1, kadınlarda \%3,0, toplamda $\% 8,0$ 'dir. ${ }^{11}$

Türkiye Sağlık Araştırması 2019 verilerine göre alkol kullanımı erkeklerde \%23,3 kadınlarda \%6,6, toplamda \%14,9'dur. ${ }^{8}$ TBSA 2010 ve 2019 sonuçlarına göre erkeklerde en fazla alkol tüketimi 31-50 yaş arasında olup yaş arttıkça kullanım azalmaktadır.,10 Gelir getiren bir işte çalışanların \%8,8’i çalışmayanların \%2,3’ü alkol kullanmaktadır. Çalışan kesimin çoğunluğunun erkek ve genç yaşta olması alkol kullanımının çalışan grupta fazla olmasını açıklayabilir. Algılanan gelir düzeyine göre düşük geliri olanların $\% 7,9^{\prime} u$, orta düzey geliri olanların $\% 3,7$ 'si, yüksek geliri olanların ise \%3,3’ü alkollü içecek kullanmaktadır. Gelir düzeyi düşük grupta alkol kullanımının fazla olması ekonomik şartların getirdiği sıkıntılarla başa çıkma yolu olarak kişilerin alkol kullanımına yönelmesi olabileceği bu konuda çalışılması gerektiği çıkarımına varılmıştır. Son dönemde yapılan çalışmalar alkol kullanımının hızlı bir artış içinde olduğunu net bir şekilde ortaya koymaktadir.

Yetersiz fiziksel aktivite kalp ve damar hastalıkları için bağımsız bir risk faktörüdür. ${ }^{12,13}$ Çalışma grubunda fiziksel aktivite yapma durumu ağır düzey için hızlı tempo yürüyüş, ağır kaldırma, odun kesme, bahçede çukur kazma gibi örnekler verilerek sorgulanmıştır. Orta düzey fiziksel aktivite için yürüyüş, hafif bahçe işleri, bisiklete binme gibi örnekler verilmiştir. Doğancı Köyü kırsal bir bölge olup kişiler geçimini büyük oranda tarım ve hayvancılıkla sağlamaktadır. Fiziksel aktiviteye ilişkin bulgular bu bağlamda değerlendirilmelidir.

Çalışma grubunun \%61,3'ü fiziksel aktivite yapmaktadır (Tablo 4). TKrHRF (Türkiye Kronik Hastalıklar ve Risk Faktörleri Sıklığı Çalışması) 2011 çalışması sonuçlarına göre erkeklerin \%23'ü yeterli, \%22'si orta düzey, \%55’i düşük düzeyde fiziksel aktivite yapmakta, kadınların ise \%13’ü yeterli, \%18’i orta, \%69’u düşük düzeyde fiziksel aktivite yapmaktadır. ${ }^{4}$ Türkiye Hane Halkı Sağlık Araştırması 2017’ye göre yüksek fizik aktivite her iki cins için \%26,8'dir. ${ }^{11}$ Güncel literatür arası farklar fiziksel aktivitenin sorgulanması ve değerlendirilmesi ile ilişkili olabilir. $\mathrm{Bu}$ çalışmada günlük yapılan işler fiziksel aktiviteye dahil edildiğinden oranlar yüksek bulunmuş olabilir. Doğancı 
Köyü’nde ise erkeklerin \%65,7'si kadınların \%57,1'i fiziksel aktivite yapmaktadır. Çalışmalar kadınların daha az fiziksel aktivite yaptığını göstermektedir. Çalışma grubunda evli olanların \%62,5'i, boşanmış-eşi ölmüş olanların $\% 47,0$ 'si bekarların ise \%64,0'ü fiziksel aktivite yapmaktadır. Boşanmış-eşi ölmüş grubun yaş ortalamasının daha yüksek olabileceği göz önünde bulundurulduğunda bu grupta fiziksel aktivite yapmanın daha az olacağı düşünülebilir.

Obezite toplumda görülme sıklığ giderek artan bir halk sağlığı sorunudur. Araştırmaya katılan erkeklerin \%22,9’u kadınların \%39,3’ü obezdir (Tablo 5). Türkiye Hane Halkı Sağlık Araştırması 2017 sonuçlarına göre erkeklerin \%21,6's1, kadınların \%35,9'u, toplumun ise \%28,8'i obezdir.11 TBSA 2019'a göre erkeklerde 15 ve üzeri yaşın \%1.2'i zayıf, \%34.3'ü normal, \%39.9'u fazla kilolu, \%23.3'ü obez, $\% 1.3$ 'si ise morbid obezdir. Kadınlarda 15 ve üzeri yaşın \%2.1'i zayıf, \%31.2'si normal, \%27.6'sı fazla kilolu \%32.7'si obez, \%6.4'ü ise morbid obezdir.9 TUİK’e göre 15 yaş ve üstü obez bireylerin oranı 2016 yılında \%19,6 iken, 2019 yılında \%21,1'dir. 2019 yılında kadınların \%24,8'inin obez ve \%30,4'ünün fazla kilolu, erkeklerin ise \%17,3'ünün obez ve \%39,7'sinin fazla kiloludur. Çalışmalar toplumun 2/3'ünün fazla kilolu ve ya obez olduğunu göstermektedir. Kadınlarda her yaş grubunda obezite erkeklerden fazladır. Geçen yillar içerisinde obezitenin her iki cinsiyet için de artış eğilimde olduğu ortadadır.

Hipertansiyon kardiyovasküler hastalıklar ve serebrovasküler hastalıklar için bilinen en önemli risk faktörlerinden birisidir. Daha önceden hekim tarafından hipertansiyon tanısı alanlar ve ölçüm sırasında sistolik kan basıncı 140 ve/veya diyastolik kan basıncı 90 mmHg’nin üzerinde ölçülenler hipertansiyon sıklığını oluşturmaktadır. Buna göre Doğancı Köyü’nde hipertansiyon sıklığı \%37,7 olup, erkeklerin \%34,5'i kadınların \%40,6'sı hipertansiyon hastasıdır (Tablo 6). Türkiye Hane Halkı Sağlık Araştırmas1 2017 sonuçlarına göre erkeklerin \%26,1'i kadınların \%29,3’ü, toplumun \%27,7'si hipertansiyon hastasıdır. ${ }^{11}$
Çalışmalar yıllar içerisinde hipertansiyon sıklığının arttığını ve kadınlarda erkeklere göre daha fazla olduğunu göstermektedir. Çalışma grubunda hipertansiyon sıklığı ulusal çalışmalardan oldukça yüksek bulunmuştur. Bu durumun detaylı analiz edilmesi gerekmektedir. Doğancı Köyü’nde yüksek tansiyonun kadınlarda daha fazla görülmesi erkeklere nispeten fiziksel aktivite azlığı ve obezitenin kadınlarda daha fazla olmasından kaynaklanıyor olabilir. Çalışma grubunda hipertansiyon sıklığı 50 yaş altında \%19,8, 50 yaş ve üzerinde $\% 58,7$ 'dir. TKrHRF Çalışmasında 2534 yaş grubunda sıklık \%5,2, 65-74 yaş grubunda \%67,1 olarak hesaplanmıştır. ${ }^{4}$ Çalışmalar hipertansiyonun yaşla arttığını göstermektedir.

Doğancı Köyü’nde yürütülen bu çalışmada obez olanların \%57,0'si hipertansiyon hastasıdır. Bel çevresi geniş olanlarda hipertansiyon sıklı̆g $1 \% 43,5$, BKO fazla olanlarda hipertansiyon sıklığı \%41,2'dir (Tablo7). Obezite artmış kan basıncı ile ilişkili olduğu bilinmektedir. Kilo alımının kan basıncı artışındaki ana belirleyicilerden biri olduğu anlaşılmaktadır. Çalışmalar obezite göstergelerinin hipertansiyon ile ilişkisini ortaya koymaktadır.

\section{SONUC}

Kalp ve damar hastalıkları dünyada ve ülkemizde önde gelen ölüm nedenlerindendir. Kalp ve damar hastalıklarının önlenmesi için ilişkili risk faktörleri analiz edilmeli bunlara yönelik müdahale programları geliştirilmelidir. Başlıca kalp ve damar hastalıkları risk faktörleri tütün ve alkol kullanımı, obezite ve hipertansiyondur. Bu çalışmada bu risk faktörlerinin sıklığı ve ilişkili sosyodemografik durumlar ele alınmıştır. Çalışma sonuçlarına göre tütün ve alkol kullanımı erkeklerde; obezite ve hipertansiyon ise kadınlarda daha fazladır. Genç yaş grubunda tütün ve alkol kullanımı yaygın olup, önleme faaliyetleri kapsamında gençler ön plana alınmalıdır. 


\section{Etik Kurul Onayı}

Araştırma için Abant İzzet Baysal Üniversitesi Sos-

yal Bilimlerde İnsan Araştırmaları Etik Kurulundan

09.12.2015 tarihli toplantısinda 2015/163 protokol nu-

marası ile etik izin alınmıştır. 
Sakarya Tip Dergisi 2021;11(4):897-907

ONUR ve Ark., Kalp ve Damar Hastalıkları Risk Faktörleri

\section{References}

1. Türk Kardiyoloji Derneği Ulusal Kalp Sağlğ̆ı Politikası, Türk Kardiyoloji Derneği Arşivi http://www.tkdonline.org/uksp/tkd_ulusalkalpsagligipolitikasi_taslak.pdf Erişim Tarihi: 03.01.2016.

2. Ölüm ve Ölüm Nedeni İstatistikleri 2019, https://data.tuik.gov.tr/Bulten/Index?p=Olum-ve-Olum-Nedeni-Istatistikleri-2019-33710 Erișim Tarihi: 04.11.2021

3. WHO, STEP wise Approach to Surveillance (STEPS). http://www.who.int/chp/steps/riskfactor/en/index.html Erişim Tarihi: 17.01.2016.

4. Ünal B, Ergör G. Türkiye Kronik Hastaliklar ve Risk Faktörleri Sıkllğı Çalıșması, T.C. Sağllk Bakanlığı Türkiye Halk Sağlğ̆ Kurumu. Ankara, Türkiye. 2013; S: 43-83, 129-145

5. WHO report on the global tobacco epidemic 2021, https://www.who.int/teams/health-promotion/tobacco-control/global-tobacco-report-2021 Erişim tarihi: 05.11.2021

6. Küresel Yetişkin Tütün Araștırması 2012, Türkiye Raporu. T.C. Sağlık Bakanlı̆̆ı Halk Sağlığı Kurumu, Ankara, Türkiye. 2014; S: 33-55, 67-79.

7. Öntaș E, Aslan D; Küresel Yetişkin Tütün Araștırmasi Türkiye 2016 - HÜTF Halk Sağhlğı AD Toplum İçin Bilgilendirme Serisi-(2018/2019-63) http://www.halksagligi.hacettepe.edu. tr/ Erişsim Tarihi: 05.11.2021
8. Türkiye Săgltk Araștrrmast, 2019 https://data.tuik.gov.tr/Bulten/Index?p=Turkey-Health-Survey-2019-33661 Erişim Tarihi: 05.11.2021

9. Besler T, Ersoy G, Karaağaoğlu N, Pekcan G. Türkiye Beslenme ve Sağlık Araștırmast, Beslenme Durumu ve Alışkanlıklarının Değerlendirilmesi Sonuç Raporu. Ankara, 2014

10. Türkiye Beslenme ve Sağllk Araștırması,https://hsgm.saglik.gov.tr/depo/birimler/saglikli-beslenme-hareketli-hayat-db/Yayinlar/kitaplar/TBSA_RAPOR_KITAP_20.08.pdf

11. Türkiye Hane Halkı Sağlık Araștırması Bulaşıcı Olmayan Hastalıkların Risk Faktörleri 2017,https://www.who.int/ncds/surveillance/steps/WHO_Turkey_Risk_Factors_A4_ TR_19.06.2018.pdf

12. Türkiye Sağlıklı Beslenme ve Hareketli Hayat Programı 2013-2017. T.C. Sağlık Bakanlı̆̆ Türkiye Halk Sağlığı Kurumu, Ankara, Türkiye. 2013

13. Türkiye Fiziksel Aktivite Rehberi. T.C. Sağlık Bakanlı̆̆ Türkiye Halk Sağllğı Kurumu, Ankara, Türkiye. 2014; S: 1-4. 